\title{
Resistance of Petunia Phenotypes to Botrytis cinerea
}

\section{Kimberly H. Krahl and William M. Randle \\ Department of Horticulture, University of Georgia, Athens, GA 30602}

Additional index words. Petunia hybrida, P. axillaris, P. integrifolia, disease resistance, gray mold, Botrytis blight, germplasm, artificial inoculation

Abstract. Although Petunia hybrida Vilm., a major bedding plant, is susceptible to many diseases, no formal disease resistance studies have been conducted. Botrytis cinerea Pers. ex Fr. is a ubiquitous pathogen, causing great damage to greenhouse-grown ornamental crops, including petunia. In this study, a screening procedure for $\boldsymbol{B}$. cinerea resistance in petunia was developed and $\mathbf{4 8}$ diverse petunia phenotypes were screened for resistance to $B$. cinerea in two seasons, spring and fall. The range of variability for resistance to $B$. cinerea in petunia was wide and continuous. Spearman's rank correlation coefficients between seasons were significant and moderate. While the majority of phenotypes displayed less than a $10 \%$ difference in mean percent infection in spring vs. fall seasons, several phenotypes displayed large differences that require further testing. One cultivar, 'Pink Sensation Improved', exhibited low and consistent mean percent infection in both spring and fall and, therefore, may be a useful source of resistance to $B$. cinerea in petunia.

Botrytis diseases are the most common and among the most destructive diseases of greenhouse-grown ornamental crops (Agrios, 1988). Botrytis blight, or gray mold, is caused by $B$. cinerea Pers. ex Fr., a ubiquitous and non-host specific facultative parasite, which affects a very wide range of species, including petunia. Initial infection typically occurs on senescent tissue. Once established, B. cinerea may invade surrounding healthy tissue (Blakeman, 1980). Leaf spots caused by $B$. cinerea usually appear as sunken, pale brown lesions. Blossom blights and fruit rots caused by $B$. cinerea are characterized in later stages by the appearance of distinctive conidia and conidiophores giving the fungus its common name, gray mold. Development of Botrytis blight is favored by a warm, humid environment and lush vegetative growth (Moody, 1991). These conditions are commonly found in production greenhouses where crowding and high nitrogen fertilization contribute to create optimal conditions for disease development. A combination of cultural controls, including increased ventilation, wider plant spacing, and proper fungicidal sprays, can be effective in controlling Botrytis blight. However, ever-rising costs of energy and labor encourage growers to maximize production in available greenhouse space. Fungicidal control is both environmentally and economically expensive. Demonstrated resistance of Botrytis strains to several commonly employed fungicides (Moorman, 1988) plus increasingly restrictive licensing policies for fungicides make alternative methods of control desirable. Identification of genetic resistance to Botrytis blight would provide a low-impact alternative to chemical con-

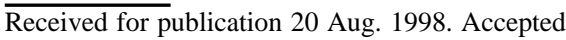
for publication $23 \mathrm{Dec}$. 1998. The cost of publishing this paper was defrayed in part by the payment of page charges. Under postal regulations, this paper therefore must be hereby marked advertisement solely to indicate this fact. trol. No qualitative resistance to Botrytis cinerea is known to occur in any species (Jarvis, 1977). While some resistance to Botrytis blight has been observed in petunia cultivars (Ewart, 1984; Weddle, 1976), no study has been conducted to develop screening techniques for the identification of possible sources of resistance to $B$. cinerea in petunia. In the present study, a procedure for screening petunias for resistance to $B$. cinerea was developed and 48 diverse petunia phenotypes were screened for resistance.

\section{Materials and Methods}

Botrytis inoculum. Petunia flowers and leaves showing symptoms of Botrytis blight were collected from several different phenotypes of mature greenhouse-grown plants in the late fall of 1992. Segments cut from the margins of lesions were surface-sterilized for $1 \mathrm{~min}$ in $10 \% \mathrm{NaOCl}$, rinsed in sterile distilled water, and transferred to petri dishes containing potato-dextrose agar (PDA). Resulting mycelia were transferred to petri dishes containing PDA and grown at ambient laboratory temperature $\left(23\right.$ to $25^{\circ} \mathrm{C}$ ) under continuous fluorescent light to promote sporulation.

Plant inoculation. The experiment was conducted in a greenhouse using a completely randomized design during two seasons, early spring and late fall 1993. Treatment 1 (natural inoculum) consisted of wounding plus application of sterile deionized water and $\approx 0.02 \%$ (v/v) Tween 20 detergent. Treatment 2 (artificial inoculum) consisted of wounding plus application of a suspension containing $1 \times 10^{6}$ spores $/ \mathrm{mL}$ sterile deionized water and $\approx 0.02 \%$ (v/v) Tween 20. With each treatment, 10 leaves per plant were wounded by burning $<5 \%$ of the upper mid-blade surface with a heated laboratory spatula tip ( $\approx 8 \mathrm{~mm}$ wide). A 10 -mL droplet with or without inoculum was applied to each wound. Plants were randomly placed in a dew chamber maintained at $100 \%$ relative humidity in an unheated greenhouse with no supplemental lighting. After $8 \mathrm{~d}$, incidence of infection was assessed. Development of sunken brown lesions extending beyond the periphery of the burn wound was defined as B. cinerea infection and the fungus was re-isolated from these lesions. Each phenotype was treated and assessed three times (three replications) per season. Infection was calculated as the mean percentage of leaves out of a total of $30(10$ leaves per plant $\times$ three plants per phenotype) that developed spreading lesions.

Assessment of resistance. Forty-eight phenotypes of petunia, including modern and older cultivars, inbred breeding lines, and accessions of the purported progenitor species of $P$. hybrida, were screened for resistance to $B$. cinerea. Seeds of the nine inbred breeding lines (MSP 1, MSP 2, MSP 4, MSP 5, MSP 6, MSP 89-34A, MSP 90-14A, MSP 90-17A, and MSP90-53A) were supplied by Dr. Lowell Ewart of Michigan State Univ. Modern cultivars were donated by: Goldsmith Seeds, Gilroy, Calif.; Harris Seeds, Rochester, N.Y.; Pan American Seed, West Chicago, Ill.; Royal Sluis Seeds, Salinas, Calif.; S \& G Seeds, Downers Grove, Ill.; and Sakata Seed America, Salinas, Calif. Older cultivars and accessions of the purported progenitor species of $P$. hybrida Hort., $P$. axillaris Lam., and $P$. integrifolia Hook., were obtained from the U.S. Dept. of Agriculture, Seed Storage Laboratory, Fort Collins, Colo.

Statistical analysis. Mean percent infection was analyzed using Proc ANOVA with multiple comparisons within season determined using Duncan's multiple-range test (SAS Institute, 1988). Spearman's correlation coefficients were calculated to assess consistency of phenotype rank order over seasons.

\section{Results and Discussion}

The two inoculation methods were analyzed separately because of the extremely high $\mathrm{F}$ value $(\mathrm{F}=4446.65, P<0.0001)$ resulting from a combined analysis, and a very high $\mathrm{F}$ value for the phenotype $\times$ treatment interaction. The phenotype $\times$ season interaction was significant for both treatment analyses; therefore, the phenotype $\times$ season term was used as the error term in the analysis of variance for each treatment (Table 1). Mean percent infec-

Table 1. Analysis of variance for mean percent infection of 48 petunia phenotypes by Botrytis cinerea.

\begin{tabular}{lcc}
\hline \hline Source & $\mathrm{df}$ & $\mathrm{MS}$ \\
\hline \multicolumn{1}{c}{ Treatment 1: wounding, natural inoculum } \\
Season & 1 & $0.40^{* * *}$ \\
Phenotype $^{z}$ & 47 & $0.21^{* * *}$ \\
Phenotype $\times$ season & 47 & $0.03^{*}$ \\
Error & 192 & 0.02 \\
Treatment 2: wounding, with artificial & inoculum \\
Season & 1 & $0.06^{*}$ \\
Phenotype & & $0.14^{* * *}$ \\
Phenotype $\times$ season & 47 & $0.03^{* * *}$ \\
Error & 192 & 0.01
\end{tabular}

${ }^{2}$ Phenotype $\times$ season is the error term for testing phenotype effect.

, ${ }^{* * *}$ Significant at $P=0.05$ or 0.001 , respectively. 
tion differed significantly among phenotypes for both treatments in each season. Although the phenotype $\times$ season interaction was significant for each treatment, the estimate of the variance component for phenotype (using natural inoculum) was 10 times as great as the variance component for phenotype $\times$ season interaction. For artificial inoculation, the estimate of the variance component for phenotype was $>2.5$ times as great as the variance component for the phenotype $\times$ season interaction. Thus, the effect of season on the phenotypic expression for $B$. cinerea infection with each treatment was small.

Spearman's correlation coefficients between spring and fall season were significant for each inoculum treatment $(r=0.77$ and 0.65 for natural and artificial inoculum, respec- tively; $P=0.05$ ) indicating a moderate level of phenotype rank order consistency between spring and fall for each treatment. However, Spearman's correlation coefficient for natural and artificial inoculum over seasons was extremely low and nonsignificant, indicating a lack of phenotype rank order consistency between the two treatments over seasons.

The range of variability in the 48 petunia phenotypes for mean percentage of infection by $B$. cinerea was wide and continuous (Tables 2 and 3). Using natural inoculum, the range in spring was from 0 to $77 \%$ mean infection, with a mean over all phenotypes of $25 \%$ (Table 2 ). The range in fall for natural inoculum was from 0 to $60 \%$ mean infection, with a mean over all phenotypes of $13 \%$. Since spores of $B$. cinerea are ubiquitous in production green-

Table 2. Mean percent infection of 48 petunia phenotypes by Botrytis cinerea in two seasons using natural vs. artificial inoculation.

\begin{tabular}{|c|c|c|c|c|}
\hline \multirow[b]{3}{*}{ Phenotype $^{z}$} & \multicolumn{4}{|c|}{ Mean percent infection } \\
\hline & \multicolumn{2}{|c|}{ Natural inoculation } & \multicolumn{2}{|c|}{ Artificial inoculation } \\
\hline & Spring & Fall & Spring & Fall \\
\hline Satellite & $0 \mathrm{a}$ & $3 a b^{y}$ & $93 \mathrm{~g}-\mathrm{i}$ & $90 \mathrm{~g}-\mathrm{j}$ \\
\hline Linda & $0 \mathrm{a}$ & $0 \mathrm{a}$ & $83 \mathrm{e}-\mathrm{i}$ & $83 \mathrm{e}-\mathrm{j}$ \\
\hline Venus & $0 \mathrm{a}$ & $3 a b$ & $83 \mathrm{e}-\mathrm{i}$ & $83 e-j$ \\
\hline Neptune & $3 a b$ & $3 a b$ & $87 \mathrm{f}-\mathrm{i}$ & $90 \mathrm{~g}-\mathrm{j}$ \\
\hline P. axillaris NSL 88812 & $3 a b$ & $0 \mathrm{a}$ & $73 \mathrm{c}-\mathrm{f}$ & $97 \mathrm{ij}$ \\
\hline Inca & $3 a b$ & $3 a b$ & $67 \mathrm{c}-\mathrm{e}$ & $80 \mathrm{~d}-\mathrm{i}$ \\
\hline Snowbird & $3 a b$ & $10 \mathrm{a}-\mathrm{d}$ & $57 \mathrm{bc}$ & $67 \mathrm{~d}-\mathrm{f}$ \\
\hline Cherry Tart & $3 a b$ & $3 a b$ & $60 b-d$ & $73 \mathrm{~d}-\mathrm{g}$ \\
\hline Crusader & $3 a b$ & $3 a b$ & $93 \mathrm{~g}-\mathrm{i}$ & $93 \mathrm{~h}-\mathrm{j}$ \\
\hline Pink Cheeks & $3 a b$ & $0 \mathrm{a}$ & $100 \mathrm{i}$ & $100 \mathrm{j}$ \\
\hline Pink Desire & $3 a b$ & $0 \mathrm{a}$ & $83 \mathrm{e}-\mathrm{i}$ & $83 \mathrm{e}-\mathrm{j}$ \\
\hline Comanche & $7 a-c$ & $0 \mathrm{a}$ & $33 \mathrm{a}$ & $70 \mathrm{~d}-\mathrm{g}$ \\
\hline MSP 90-53A & $7 a-c$ & $3 a b$ & $97 \mathrm{hi}$ & $97 \mathrm{ij}^{\circ}$ \\
\hline MSP 6 & $7 a-c$ & $0 \mathrm{a}$ & $100 \mathrm{i}$ & $100 \mathrm{j}$ \\
\hline Pink Sensation Improved & $7 a-c$ & $7 a-c$ & $23 \mathrm{a}$ & $23 \mathrm{a}$ \\
\hline Howard's Star Improved & $7 a-c$ & $0 \mathrm{a}$ & $50 \mathrm{~b}$ & $70 d-g$ \\
\hline P. integrifolia NSL 88813 & $7 \mathrm{a}-\mathrm{c}$ & $0 \mathrm{a}$ & $93 \mathrm{~g}-\mathrm{i}$ & $87 \mathrm{f}-\mathrm{j}$ \\
\hline Calypso & $10 a-c$ & $0 \mathrm{a}$ & $87 \mathrm{f}-\mathrm{i}$ & $83 e-j$ \\
\hline Extra Dwarf Giant & $10 a-c$ & $3 a b$ & $100 \mathrm{i}$ & $93 \mathrm{~h}-\mathrm{j}$ \\
\hline Comet & $10 a-c$ & $0 \mathrm{a}$ & $100 \mathrm{i}$ & $40 \mathrm{ab}$ \\
\hline Sugar Daddy & $13 \mathrm{a}-\mathrm{d}$ & $7 \mathrm{a}-\mathrm{c}$ & $97 \mathrm{hi}$ & $97 \mathrm{ij}$ \\
\hline Primetime Blue & $13 \mathrm{a}-\mathrm{d}$ & $13 \mathrm{a}-\mathrm{d}$ & $90 \mathrm{f}-\mathrm{i}$ & $83 \mathrm{e}-\mathrm{j}$ \\
\hline Purple Wave & $13 \mathrm{a}-\mathrm{d}$ & $0 \mathrm{a}$ & $100 \mathrm{i}$ & $100 \mathrm{j}$ \\
\hline Matador & $13 a-d$ & $7 \mathrm{a}-\mathrm{c}$ & $93 \mathrm{~g}-\mathrm{i}$ & $77 \mathrm{~d}-\mathrm{i}$ \\
\hline MSP 5 & $17 \mathrm{a}-\mathrm{e}$ & $7 \mathrm{a}-\mathrm{c}$ & $100 \mathrm{i}$ & $90 \mathrm{~g}-\mathrm{j}$ \\
\hline Merlin Pink & $20 \mathrm{a}-\mathrm{e}$ & $0 \mathrm{a}$ & $93 \mathrm{~g}-\mathrm{i}$ & $83 \mathrm{e}-\mathrm{j}$ \\
\hline Chiffon & $20 \mathrm{a}-\mathrm{e}$ & $0 \mathrm{a}$ & $77 \mathrm{~d}-\mathrm{g}$ & $93 \mathrm{~h}-\mathrm{j}$ \\
\hline Minuet & $20 \mathrm{a}-\mathrm{e}$ & $13 \mathrm{a}-\mathrm{d}$ & $97 \mathrm{hi}$ & $97 \mathrm{ij}$ \\
\hline Bingo & $23 \mathrm{a}-\mathrm{f}$ & $10 \mathrm{a}-\mathrm{d}$ & $100 \mathrm{i}$ & $100 \mathrm{j}$ \\
\hline Celebrity Red & $23 \mathrm{a}-\mathrm{f}$ & $7 a-c$ & $87 \mathrm{f}-\mathrm{i}$ & $87 \mathrm{f}-\mathrm{j}$ \\
\hline Fandango & $27 \mathrm{a}-\mathrm{g}$ & $7 \mathrm{a}-\mathrm{c}$ & $83 \mathrm{e}-\mathrm{i}$ & $83 \mathrm{e}-\mathrm{j}$ \\
\hline White Magic & $30 \mathrm{~b}-\mathrm{h}$ & $3 a b$ & $83 \mathrm{e}-\mathrm{i}$ & $100 \mathrm{j}$ \\
\hline MSP 89-34A & $33 c-i$ & $20 \mathrm{c}-\mathrm{e}$ & $100 \mathrm{i}$ & $93 \mathrm{~h}-\mathrm{j}$ \\
\hline P. integrifolia NSL 98077 & $33 c-i$ & $40 \mathrm{~g}-\mathrm{i}$ & $100 \mathrm{i}$ & $100 \mathrm{j}$ \\
\hline MSP 4 & $40 \mathrm{~d}-\mathrm{i}$ & $20 \mathrm{c}-\mathrm{e}$ & $80 \mathrm{e}-\mathrm{h}$ & $80 \mathrm{~d}-\mathrm{j}$ \\
\hline Rose and White Pearls & $43 e-j$ & $10 \mathrm{a}-\mathrm{d}$ & $77 \mathrm{~d}-\mathrm{g}$ & $60 \mathrm{~cd}$ \\
\hline Celebrity Raspberry Ice & $43 \mathrm{e}-\mathrm{j}$ & $10 \mathrm{a}-\mathrm{d}$ & $80 \mathrm{e}-\mathrm{h}$ & $77 \mathrm{~d}-\mathrm{i}$ \\
\hline MSP 90-17A & $50 \mathrm{f}-\mathrm{k}$ & $23 \mathrm{~d}-\mathrm{f}$ & $100 \mathrm{i}$ & $100 \mathrm{j}$ \\
\hline Hullahoop Rose & $50 \mathrm{f}-\mathrm{k}$ & $7 \mathrm{a}-\mathrm{c}$ & $97 \mathrm{hi}$ & $87 \mathrm{f}-\mathrm{j}$ \\
\hline MSP 90-14A & $53 \mathrm{~g}-\mathrm{k}$ & $20 \mathrm{c}-\mathrm{e}$ & $100 \mathrm{i}$ & $100 \mathrm{j}$ \\
\hline Maestro & $53 \mathrm{~g}-\mathrm{k}$ & $43 \mathrm{hi}$ & $100 \mathrm{i}$ & $90 \mathrm{~g}-\mathrm{j}$ \\
\hline Orchid Cloud & $53 \mathrm{~g}-\mathrm{k}$ & $27 \mathrm{e}-\mathrm{g}$ & $83 \mathrm{e}-\mathrm{i}$ & $63 c-f$ \\
\hline Ultra Rose Star & $57 \mathrm{~h}-\mathrm{k}$ & $17 b-e$ & $73 \mathrm{c}-\mathrm{f}$ & $47 \mathrm{bc}$ \\
\hline MSP 1 & $60 \mathrm{i}-\mathrm{k}$ & $40 \mathrm{~g}-\mathrm{i}$ & $97 \mathrm{hi}$ & $97 \mathrm{hi}$ \\
\hline Crimson Titan & $70 \mathrm{jk}$ & $53 \mathrm{ij}$ & $73 \mathrm{c}-\mathrm{f}$ & $80 \mathrm{~d}-\mathrm{j}$ \\
\hline MSP 2 & $70 \mathrm{jk}$ & $60 \mathrm{j}$ & $83 \mathrm{e}-\mathrm{i}$ & $77 \mathrm{~d}-\mathrm{i}$ \\
\hline Postillion Salmon & $73 \mathrm{k}$ & $37 \mathrm{f}-\mathrm{h}$ & $90 \mathrm{f}-\mathrm{i}$ & $67 \mathrm{~d}-\mathrm{f}$ \\
\hline Highlight Blue & $77 \mathrm{k}$ & $53 \mathrm{ij}$ & $93 \mathrm{~g}-\mathrm{i}$ & $60 \mathrm{~cd}$ \\
\hline
\end{tabular}

${ }^{2}$ See text for seed sources.

yMean separation within columns by Duncan's multiple range test, $P=0.05 ; \mathrm{n}=3$ for each phenotype.

houses, a certain level of infection incidence for natural inoculum was expected. The study with natural inoculum may approximate the natural potential for Botrytis disease development occurring in clean greenhouses early in the growing season. Early in the production season, when plants are small and, well spaced within and between flats or pots, air circulation is good, and humidity within the plant canopy is relatively low, there is very little senescent tissue and no established Botrytis disease. The levels of infection observed in the phenotypes treated with natural inoculum resulted from ambient levels of $B$. cinerea spores in the atmosphere.

For treatment 2 (artificial inoculum), the range was the same in each season, from $23 \%$ to $100 \%$ mean infection, with a mean over all

Table 3. Mean percent infection with Botrytis cinerea for 48 petunia phenotypes with treatment 2 (wounding plus artificial inoculum) in two seasons.

\begin{tabular}{lcc}
\hline \hline & \multicolumn{2}{c}{ Mean percent infection } \\
\cline { 2 - 3 } Phenotype & Spring & Fall \\
\hline Pink Sensation Improved & $23 \mathrm{a}$ & $23 \mathrm{a}$ \\
Comanche & $33 \mathrm{a}$ & $70 \mathrm{~d}-\mathrm{g}$ \\
Howard's Star Improved & $50 \mathrm{~b}$ & $70 \mathrm{~d}-\mathrm{g}$ \\
Snowbird & $57 \mathrm{bc}$ & $67 \mathrm{~d}-\mathrm{f}$ \\
Cherry Tart & $60 \mathrm{~b}-\mathrm{d}$ & $73 \mathrm{~d}-\mathrm{g}$ \\
Inca & $67 \mathrm{c}-\mathrm{e}$ & $80 \mathrm{~d}-\mathrm{j}$ \\
P. axillaris NSL 88812 & $73 \mathrm{c}-\mathrm{f}$ & $97 \mathrm{ij}$ \\
Ultra Rose Star & $73 \mathrm{c}-\mathrm{f}$ & $47 \mathrm{bc}$ \\
Crimson Titan & $73 \mathrm{c}-\mathrm{f}$ & $80 \mathrm{~d}-\mathrm{j}$ \\
Rose and White Pearls & $77 \mathrm{~d}-\mathrm{g}$ & $60 \mathrm{~cd}$ \\
Chiffon & $77 \mathrm{~d}-\mathrm{g}$ & $93 \mathrm{~h}-\mathrm{j}$ \\
Celebrity Raspberry Ice & $80 \mathrm{e}-\mathrm{h}$ & $77 \mathrm{~d}-\mathrm{i}$ \\
MSP 4 & $80 \mathrm{e}-\mathrm{h}$ & $80 \mathrm{~d}-\mathrm{j}$ \\
Venus & $83 \mathrm{e}-\mathrm{i}$ & $83 \mathrm{e}-\mathrm{j}$ \\
Pink Desire & $83 \mathrm{e}-\mathrm{i}$ & $83 \mathrm{e}-\mathrm{j}$ \\
Linda & $0.83 \mathrm{e}-\mathrm{i}$ & $83 \mathrm{e}-\mathrm{j}$ \\
MSP 2 & $83 \mathrm{e}-\mathrm{i}$ & $77 \mathrm{~d}-\mathrm{i}$ \\
Orchid Cloud & $83 \mathrm{e}-\mathrm{i}$ & $63 \mathrm{c}-\mathrm{e}$ \\
Fandango & $83 \mathrm{e}-\mathrm{i}$ & $83 \mathrm{e}-\mathrm{j}$ \\
White Magic & $83 \mathrm{e}-\mathrm{i}$ & $100 \mathrm{j}$ \\
Neptune & $87 \mathrm{f}-\mathrm{i}$ & $90 \mathrm{~g}-\mathrm{j}$ \\
Calypso & $87 \mathrm{f}-\mathrm{i}$ & $83 \mathrm{e}-\mathrm{j}$ \\
Celebrity Red & $87 \mathrm{f}-\mathrm{i}$ & $87 \mathrm{f}-\mathrm{j}$ \\
Postillion Salmon & $90 \mathrm{f}-\mathrm{i}$ & $67 \mathrm{~d}-\mathrm{f}$ \\
Primetime Blue & $90 \mathrm{f}-\mathrm{i}$ & $83 \mathrm{e}-\mathrm{j}$ \\
Matador & $93 \mathrm{~g}-\mathrm{i}$ & $77 \mathrm{~d}-\mathrm{i}$ \\
P. integrifolia NSL 88813 & $93 \mathrm{~g}-\mathrm{i}$ & $87 \mathrm{f}-\mathrm{j}$ \\
Highlight Blue & $93 \mathrm{~g}-\mathrm{i}$ & $60 \mathrm{~cd}$ \\
Merlin Pink & $93 \mathrm{~g}-\mathrm{i}$ & $83 \mathrm{e}-\mathrm{j}$ \\
Crusader & $93 \mathrm{~g}-\mathrm{i}$ & $93 \mathrm{~h}-\mathrm{j}$ \\
Satellite & $93 \mathrm{~g}-\mathrm{i}$ & $90 \mathrm{~g}-\mathrm{j}$ \\
MSP 1 & $97 \mathrm{hi}$ & $97 \mathrm{ij}$ \\
Sugar Daddy & $97 \mathrm{hi}$ & $97 \mathrm{ij}$ \\
Minuet & $97 \mathrm{hi}$ & $97 \mathrm{ij}$ \\
Hullahoop Rose & $97 \mathrm{hi}$ & $87 \mathrm{f}-\mathrm{j}$ \\
MSP 90-53A & $97 \mathrm{hi}$ & $97 \mathrm{ij}$ \\
Bingo & $100 \mathrm{i}$ & $100 \mathrm{j}$ \\
P. integrifolia NSL 98077 & $100 \mathrm{i}$ & $100 \mathrm{j}$ \\
Comet & $100 \mathrm{i}$ & $40 \mathrm{ab}$ \\
MSP 6 & $100 \mathrm{i}$ & $100 \mathrm{j}$ \\
Purple Wave & $100 \mathrm{i}$ & $100 \mathrm{j}$ \\
MSP 90-14A & $100 \mathrm{i}$ & $100 \mathrm{j}$ \\
MSP 90-17A & $100 \mathrm{i}$ & $100 \mathrm{j}$ \\
MSP 89-34A & $100 \mathrm{i}$ & $93 \mathrm{~h}-\mathrm{j}$ \\
Maestro & $100 \mathrm{i}$ & $90 \mathrm{~g}-\mathrm{j}$ \\
Pink Cheeks & $100 \mathrm{j}$ \\
MSP 5 & $90 \mathrm{~g}-\mathrm{j}$ \\
Extra Dwarf Giant & $93 \mathrm{~h}-\mathrm{j}$ \\
\hline Meanseparaton by D & & \\
\hline
\end{tabular}

${ }^{2}$ Mean separation by Duncan's multiple range test, $P$ $=0.05 ; \mathrm{n}=3$ for each phenotype. 
phenotypes of $85 \%$ and $83 \%$ infection for spring and fall, respectively (Table 3). The study with artificial inoculum may approximate the natural potential for the development of Botrytis disease occurring in production greenhouses when the disease potential is high due to a combination of conditions, including poor air circulation, high humidity in the dense plant canopy, and large amounts of senescent tissue.

The continuous range of variability for mean percentage of infection with natural and artificial inoculum suggests that resistance to $B$. cinerea in petunia is quantitative. A majority of the phenotypes, including the nine inbred breeding lines and the three accessions of the purported progenitor species of $P$. hybrida, exhibited little or no resistance when artificially inoculated. In contrast, many phenotypes expressed high levels of resistance, while others were highly susceptible when inoculated naturally. A majority (70\%) of phenotypes ex- hibited less than a $10 \%$ difference in mean infection between seasons when artificial inoculum was used. Several phenotypes, including 'Comet', 'Highlight Blue', 'Postillion Salmon', 'Orchid Cloud', Ultra Rose Star', $P$. axillaris NSL88812, 'Howard's Star', and 'Comanche' differed greatly between seasons, warranting further investigation. 'Pink Sensation Improved', an older cultivar no longer commercially available, exhibited low mean percent infection (23\%) in both spring and fall when artificial inoculum was used. 'Pink Sensation Improved' may prove to be an important source of resistance to $B$. cinerea for use in breeding Botrytis-resistant petunia cultivars.

\section{Literature Cited}

Agrios, G.N. 1988. Plant diseases caused by fungi, p. 356-425. In: G.N. Agrios (ed.). Plant pathology. Academic Press, New York.
Blakeman, J.P. 1980. Behaviour of conidia on aerial plant surfaces, p. 225-248. In: J.R. Coley-Smith, K. Verhoeff, and W.R. Jarvis (eds.). The biology of Botrytis. Academic Press, New York.

Ewart,L. 1984. Plant breeding, p. 180-202. In: K.C Sink (ed.). Petunia: Monographs on theoretical and applied genetics. Springer-Verlag, New York.

Jarvis, W.R. 1977. Botryotinia and Botrytis species: Taxonomy, physiology and pathogenicity. Monograph 15, Research Branch, Canada Dept. Agr., Ottawa.

Moody, E.H. 1991. Coping with Botrytis blight-A serious disease of greenhouse grown ornamental plants in 1991. Ornamental plant pathology update. Ga. Coop. Ext. Circ. 1:4-6.

Moorman, G.W. 1988. 1988 Diseases. Coop. Reg. Project NCR-43. Annu. Rpt.

SAS Institute, 1988. SAS/STAT user's guide, release 6.03 ed. SAS Inst., Cary, N.C.

Weddle, C.L. 1976. Petunias, p. 252-270. In: J.W. Mastalerz (ed.). Bedding plants: A manual on the culture of bedding plants as a greenhouse crop. Penn. Flower Growers, University Park. 